\title{
Nori Nutrient Analysis from Seawed of Porphyra marcossi in Maluku Ocean
}

\author{
Voulda D. Loupatty \\ Balai Riset dan Standarisasi Industri Ambon \\ Jl. Kebun Cengkih, Ambon \\ E-mail :voulda_loupatty@yahoo.co.id
}

\begin{abstract}
ABSTRAK
Penelitian “Analisis Gizi Nori Dari Rumput Laut Jenis Porphyra marcossi Yang Terdapat Di Perairan Maluku" dilakukan dengan tujuan menganalisis kualitas gizi nori yang dihasilkan dari rumput laut Porphyra marcossi, yang nantinya mampu menggantikan penggunaan nori impor untuk memenuhi kebutuhan dalam negeri. Adapun prosedur kerja proses pembuatan nori adalah rumput laut kering dicuci bersih, setelah bersih dilakukan pemotongan kecil-kecil / diblender. Selanjutnya direbus dengan perbandingan rumput laut:air=1:10 dengan penambahan sedikit cuka. Perebusan dilakukan selama \pm 1 jam. Setelah itu dicetak berbentuk lembaran tipis, dikeringkan dan dikemas. Dalam penelitian ini dilakukan pengujian terhadap produk yang dihasilkan meliputi kadar protein, lemak, abu dan air, yang mengacu pada SNI 01-2891-1992, serta identifikasi asam amino dengan menggunakan metode hidrolisis asam basa.

Hasil penelitian menunjukan bahwa rumput laut Porphyra marcossi mempunyai nilai gizi yang cukup tinggi yaitu : protein $28,60 \%$; lemak $0,83 \%$; abu $17,80 \%$ dan air 28,09\%. Produk Nori mempunyai nilai gizi : protein $41,49 \%$; lemak $0,44 \%$;abu 4,99\%; air 13,14\%. Terdapat 10 jenis asam amino yaitu treonin, arginin, tirosin, meteonin, lisin, valin, asam glutamate, glisin, fenilalanin dan alanin. Teknologi pengolahan Nori cukup sederhana dan mudah dikembangkan dalam industry rumah tangga untuk meningkatkan pendapatan keluarga. Kebutuhan Nori dalam negeri dapat dipenuhi dengan adanya indutri pengolahan nori berbasis sumber daya alam lokal.
\end{abstract}

Kata kunci : Porphyra marcossi, Perairan Maluku, Nori, Gizi

\section{ABSTRACT}

Research about "Nori Nutient Analysis From seaweed Of Porphyra marcossi In Maluku Ocean" is carried out with the aim for analysis nori nutrient from Porphyra marcossi seaweed, thatwill be able toreplacethe use of nori-imports. tofulfill domestic demand. The processing stage are the dried seaweed washed clean and cut into small pieces or in blender, after thatboiled with comparison seaweed: water=1:10with addition littlevinegar. Boiling is done for approximately 1 hour. And printed form thin sheets, dried and packaged. In this research also testing the products produced include protein, fat, ash and water, which refers to SNI 01-2891-1992 and amino acid identification use alkaliacid hydrolysis method.

The results showed that Porphyra marcossi seaweed has high value nutrient such as protein $28,60 \%$; fat 0,83\%; ash 17,80\% and water $28,09 \%$ and nutrient in nori seaweed product for protein 41.49\%; fat 0.44\%; ash 4.99\% ;water 13.14\% .The amino acid was obtained treonine, arginine, tyrosine, methionine, lysine,valine, glutamate acid, glysine, phenylalanine, alanine. Nori processing technology is quite simple and easy to develop to home industry to increase household income. Domestic needs of nori can be met with processing industry based on local natural resources.

Keywords : Porphyra marcossi, Maluku Ocean, Nori, Nutrient 


\section{Pendahuluan}

Istilah rumput laut (seaweed), lazim dikenal dalam dunia perdagangan. Dalam ilmu pengetahuan dikenal dengan sebutan alga. Alga termasuk tanaman tingkat rendah, karena tidak mempunyai akar, batang, daun dan bunga khusus. Pada umumnya alga dikelompokan menjadi 4 kelas berdasarkan kandungan pigmennya, yaitu Rhodophyceae (alga merah), Phaeophyceae (alga coklat), Chlorophyceae (alga hijau), Cyanophyceae (alga biru - hijau) (Othmer,1968; Soegiarto dkk., 1978; Aslan, 1998). Selanjutnya dikatakan bahwa pigmen utama yang menentukan warna pada rumput laut adalah klorofil, karoten, phycoerithyn dan floridin starch, monoglyserate dan phycocyanin, disamping pigmen-pigmen floridoside.

Tabel 1. Kandungan Pigmen Utama Alga

\begin{tabular}{|c|c|c|c|c|}
\hline Kelas alga & Klorofil & Karoten & Phycoerithyn & Phycocyanin \\
\hline Alga hijau & a \& b & B & - & - \\
\hline Alga coklat & a \& c & B & - & - \\
\hline Alga merah & a & B & + & + \\
\hline Alga biru & a & B & + & + \\
\hline
\end{tabular}

Sejak zaman dahulu rumput laut telah dimanfaatkan oleh bangsa Cina dan Jepang sebagai makanan yang istimewa maupun sebagai obat-obatan. Di Jepang terdapat 21 varietas sayuran laut yang digunakan dalam masakan setiap hari. Konsumsi rumput laut masyarakat Jepang mencapai $10 \%$ dari kebutuhan pangannya. (Winarno, 1990). menjadi yang paling meguntungkan,

lainnya, pigmen ini pula yang menentukan warna thallus sesuai dengan pigmen yang ada pada masing-masing kelas rumput laut. Phycoerithyn dan phycochyanin hanya didapati pada Rhodophyceae dan Cyanophyceae, sedangkan klorofil dan karoten dijumpai pada ke empat kelas rumput laut tersebut, hanya jumlahnya berbeda-beda. Jenis pigmen yang terkandung dalam rumput laut dapat dilihat pada Tabel 1.

Dari hasil fotosintesa chlorophyta menghasilkan pati (starch) dan lemak, Phaeophyta menghasilkan manitol (gula alkohol), laminaria, sellulosa, algin dan fukoin, sedangkan Rhodophyta menghasilkan

floridoside. 
diantaranya adalah green laver (aonori) dan porphyra (purple laver nori); laminaria (kombu); wakame, dan hizikia (hiziki).

Nori adalah nama dalam bahasa Jepang untuk bahan makanan berupa lembaran rumput laut yang dikeringkan. Nori digunakan sebagai hiasan dan penyedap berbagai macam masakan Jepang, lauk sewaktu makan nasi, dan bahan makanan ringan seperti senbei. Bahan baku adalah alga jenis Porphyra seperti Porphyra pseudolinearis Ueda yang dikenal sebagai Iwanori dan Porphyra yezoensis Ueda.

Teknologi pengolahan nori dapat dilakukan dengan 2 (dua) cara yaitu cara tradisional dan cara modern. Pengolahan secara tradisional adalah: rumput laut dicuci bersih, kemudian dimasak sampai menjadi bubur. Selanjutnya bubur rumput laut dicetak dan dikeringkan dengan sinar matahari (Tanikawa 1971; Wikipedia, 2012). Sedangkan teknologi pengolahan nori secara modern adalah: rumput laut dicuci bersih dan dipotong kecil-kecil secara mekanik. Hasil pemotongan dapat direndam dengan cuka beras ataupun tidak. Selanjutnya dimasak sampai menjadi bubur. Dalam proses perebusan dapat ditambahkan kecap, gula, minyak wijen, MSG ataupun ikan teri. Selanjutnya dicetak dan dikeringkan menjadi lembaran tipis (Wikipedia, 2012; Korringga, 1976; Terramoto, 1990).

Jepang, RRC, dan Korea merupakan produsen nori terbesar di dunia. Di RRC, nori disebut sebagai hăitái, dan di Korea disebutgim. Korea terkenal dengan nori berbumbu minyak wijen, cabai, dan butiran garam yang agak kasar sehingga berbau khas dan terasa agak pedas (Wikipedia,2012 ; Kusumanto,2013). Data hasil produksi nori mencapai 2 milyar lembar per tahun (Kuda et al. 2004).

Berkembangnya restoran Cina dan Jepang yang menyajikan menu siap saji di Indonesia menyebabkan kebutuhan nori meningkat $80 \%$ (Teddy, 2009). Selanjutnya dalam upaya memenuhi kebutuhan nori dalam negeri, maka Ia melakukan penelitian pembuatan nori secara tradisional dari rumput laut jenis Gracilaria sp. Nori yang dihasilkan dalam penelitian ini berwarna hijau muda kecoklatan, dengan kandungan gizi: kadar air 15,44\%, kadar abu 5,23\%, protein $6,20 \%$, dan karbohidrat 73,03\%.

Dibandingkan Cina dan Jepang, pemanfaatan rumput laut dalam pangan Indonesia masih sangat kecil, belum memasyarakat hanya penduduk yang bermukim di pesisir pantai telah memanfaatkan beberapa jenis rumput laut sebagai bahan makanan. Tingkat 
kesukaannya berbeda antara daerah yang satu dengan daerah yang lainnya. Hal ini berkaitan dengan distribusi atau penyebaran jenis alga yang dominan pada suatu daerahdengan musim tertentu., dan biasanya dikonsumsi dalam keadaan segar.

Di Maluku khususnya disekitar Pulau Ambon terdapat salah satu jenis rumput laut merah yang biasa dikonsumsi masyarakat pesisir pantai yang dikenal dengan nama daerah Huang isi atau sayur isi atau disebut juga lumu-lumu licin, sedangkan nama ilmiahnya yaitu Porphyra marcossi. Rumput laut Porphyra sptermasuk jenis rumput laut merah, menurut Chapman and Chapman (1980) diklasifikasikan sebagai berikut :

$\begin{array}{ll}\text { Kingdom } & : \text { Protista } \\ \text { Divisi } & : \text { Rhodophyta } \\ \text { Kelas } & : \text { Rhodophyceae } \\ \text { Subkelas } & : \text { Bangiophyceae } \\ \text { Ordo } & : \text { Bangiales } \\ \text { Famili } & : \text { Bangiaceae } \\ \text { Genus } & : \text { Porphyra }\end{array}$

Rumput laut merah memiliki pigmen dominan fikoeretrin dan fikosianin yang menimbulkan warna merah.

Diskripsi Porphyra marcossi menurut Cordero, (1976) dalam Hatta, dkk., (1993) adalah fase vegetative alge berwarna merah hingga merah tua, ukuran kecil sampai sedang, tinggi tidak lebih dari $7 \mathrm{~cm}$, lembaran thalli bisa bercabang, lebar mencapai $20 \mathrm{~mm}$. Keberadaannya biasanya membentuk hamparan seperti karpet di atas batuan, alat pelekat berupa cakram kecil. Tepi thalli tidak rata, mempunyai duri-duri halus, terdiri dari satu atau dua sel, panjang mencapai $30 \mu \mathrm{m}$, jarak berbentuk segiempat atau polygonal, tersusun tidak teratur, panjang $20-30 \mu \mathrm{m}$, lebar $15-20 \mu \mathrm{m}$, berdinding tebal. Irisan melintang thalli monostromatus, berupa pipa, tebal 15 $20 \mu \mathrm{m}$, yang terdiri atas satu deretan sel-sel berbentuk segiempat atau bulat, lebar $6-9$ $\mu \mathrm{m}$ dan panjang 12 - $17 \mu \mathrm{m}$. Sel-sel berdinding tebal dengan zat warna merah yang tersebar di seluruh bagian sel. Fase konkhoselis berupa bintik-bintik merah, mikroskopis, menyerupai benang pendek yang menempel pada batu karang. Fase ini sulit sekali dipisahkan dari substratnya.

Di Indonesia jenis rumput laut Porphyra sp,tumbuh secara alamiah dan tersebar di Maluku, Papua dan Teluk Bitung (DKP, 2009). Di Maluku rumput laut jenis Porphyra marcossi ini tumbuh pada substrat berkarang disepanjang pantai di zona pasang surut bagian atas yang selalu mendapat hempasan ombak besar menyebabkan tempat tersebut tetap basah. Biasanya terdapat dalam jumlah yang banyak pada musim penghujan 
yaitu dari bulan Juni sampai dengan bulan September. Setelah panen pertama rumput laut ini masih bisa dipanen berulang kali dengan masa istirahat 10 hari. Namun produksi ini hanya dimanfaatkan oleh masyarakat pesisir pantai dalam bentuk segar dan disimpan dalam bentuk kering untuk dikonsumsi sendiri. Padahal jenis rumput laut ini dapat dibuat nori untuk meningkatkan nilai ekonominya. Dengan adanya kemampuan memproduksi nori yang berbahan baku dari perairan di Indonesia maka diharapkan produksi nori dalam negeri secara bertahap akan mampu menggantikan penggunaan nori impor.

\section{Tujuan Penelitian/ Tujuan Penulisan}

Adapun tujuan dari penelitian ini adalah untuk menganalisis kualitas gizi Nori yang dihasilkan dari rumput laut Porphyra marcossi dan diharapkan nantinya akan mampu menggantikan penggunaan nori impor untuk memenuhi kebutuhan dalam negeri.

\section{Metode Penelitian/ Metode Penulisan}

1. Bahan dan Alat

Bahan yang digunakan dalam penelitian ini adalah: rumput laut jenis Porphyra marcossi, dan cuka beras untuk pembuatan nori, sedangkan alat yang digunakan adalah: pisau, telenan, blender, alat cetak nori, oven pengering.

\section{Prosedur Kerja}

Pembuatan Nori :

- Rumput laut dibersihkan dari kotoran lainnya dan dicuci bersih

- Selanjutnya rumput laut tersebut dipotong kecil-kecil dan diblender

- Rumput laut yang telah halus tersebut dimasak dengan perbandingan

Rumput laut:Air adalah 1:10, selanjutnya ke dalam adonan ditambahkan sedikit cuka beras \pm 1sendok makan, dan sambil di aduk rata. Proses pemasakan berlangsung sekitar 1 jam

- Selanjutnya adonan di turunkan dari api dan dicetak berbentuk, lembaran tipis

- Lembaran nori tersebut dikeringkan dengan suhu tidak lebih dari $50{ }^{\circ} \mathrm{C}$

- Hasil pengeringan yang berupa lembaran nori dikemas dalam plastik. 
Diagram alirnya dapat dilihat pada Gambar 1.

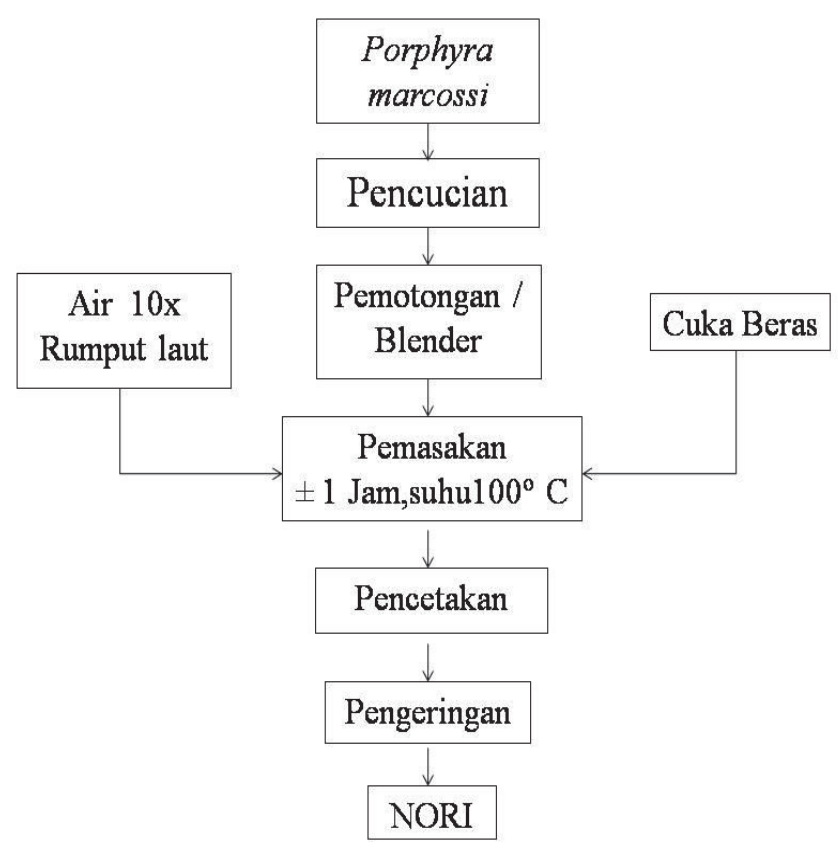

Gambar 1. Diagram Alir Proses Pembuatan Nori

Teknologi ini merupakan modifikasi dari teknologi pengolahan nori yang ada.

\section{Parameter Uji}

Dalam penelitian ini dilakukan pengujian terhadap kandungan gizi dari bahan baku (Porphyra marcossi) dan nori yang dihasilkan dari proses pengolahan rumput laut Porphyra marcossi meliputi : kadar protein, lemak, abu dan air di mana prosedur pengujian mengacu pada SNI 01 -2891 - 1992. Sedangkan identifikasi asam amino menggunakan metode hidrolisis asam-basa.

4. Teknik Analisa Data

Dalam penelitian ini teknik analisa data dilakukan dengan 2 cara yaitu:

- Data primer: diperoleh dari hasil uji laboratorium terhadap bahan baku maupun produk yang dihasilkan .

- Data sekunder: diperoleh melalui studi literatur, yang dapat digunakan untuk melengkapi kajian ini. 


\section{Hasil Dan Pembahasan}

\section{Kandungan Gizi Bahan Baku}

Hasil pengujian laboratorium terhadap komposisi gizi dalam hal ini protein, lemak, abu dan air dari rumput laut jenis Porphyra marcossi (sayur isi) dapat dilihat pada Tabel 2.

Tabel 2. Komposisi Gizi Rumput Laut Jenis Porphyra marcossi

\begin{tabular}{|c|c|c|}
\hline No. & Komponen & Hasil (\%) \\
\hline 1. & Protein & 28,60 \\
\hline 2. & Lemak & 0,83 \\
\hline 3. & Abu & 17,80 \\
\hline 4. & Air & 28,09 \\
\hline
\end{tabular}

*Hasil rata-rata 3 kali ulangan

Hasil analisa yang dilakukan Hatta, dapat ditemukan dalam Porphyra, terdapat dkk., (1993) memperlihatkan protein juga taurin yang diketahui efektif untuk 21,58\%; lemak 0,10\%; abu11,61\% dan fungsi hati, mencegah terjadinya penyakit karbohidrat 66,00\%. Berdasarkan hasil batu empedu serta mengontrol kolesterol analisa tersebut terlihat bahwa rumput laut darah. Dalam Trono and Ganzon (1988) jenis ini memiliki kandungan protein yang menyebutkan manfaat Porphyra adalah cukup tinggi yang berkisar antara $20-30 \%$. sumber vitamin B1, sumber agar serta Dalam Chapman (1970), mengatakan rumput menurunkan kolesterol. Hasil penelitian laut jenis ini lebih baik dari jenis lainnya Nitisawa (2006) di Jepang dalam karena 75\% dari protein dan karbohidrat Anonymous (2010) mencatat bahwa rumput dapat dicerna oleh tubuh manusia.

Dalam Lisa (1999) disebutkan bahwa Porphyra mengandung sejumlah protein, asam amino, vitamin A, B dan C. Asam amino alanin, asam glutamate dan glisin yang terdapat dalam Porphyra berfungsi sebagai penghasil rasa pada nori. Asam amino lainnya yaitu arginin merupakan asam amino yang biasanya terdapat dalam protein hewani. Selain beberapa asam amino yang laut Porphyra sp mampu menurunkan kadar kolesterol LDL (Low Density Lipoprotein) dan meningkatkan HDL (Hight Density Lipoprotein) dalam darah hewan uji. Di mana serat yang terdapat dalam rumput laut tersebut mampu mengikat asam empedu sehingga dapat mencegah penimbunan kolesterol dalam tubuh.

Dari uraian di atas terlihat bahwa rumput laut jenis ini mengandung nilai nutrisi 
yang cukup tinggi dan lengkap. Bahkan nilai protein dan jenis asam amino yang terkandung didalamnya membuat rumput laut ini dapat disejajarkan dengan hewan yang biasanya memiliki protein lebih tinggi dibandingkan dengan tumbuhan. Menurut Gaman dan Sherrington (1994), protein tumbuhan mempunyai nilai lebih rendah dari protein hewani. Selanjutnya menurut Desrosier (1988), jaringan tanaman biasanya merupakan sumber karbohidrat sedangkan jaringan hewani biasanya merupakan sumber protein. Dengan demikian jenis rumput laut ini perlu dipertimbangkan untuk dikembangkan penggunaannya lebih luas lagi.

\section{Kandungan Gizi Nori}

Hasil pengujian laboratorium terhadap komposisi gizi nori dalam hal ini protein, lemak, abu dan air dapat dilihat pada Tabel 3.

Tabel 3. Komposisi Gizi Nori

\begin{tabular}{|c|c|c|}
\hline No. & Komponen & Hasil ( \% ) \\
\hline 1. & Protein & 41,49 \\
\hline 2. & Lemak & 0,44 \\
\hline 3. & Abu & 4,99 \\
\hline 4. & Air & 13,14 \\
\hline
\end{tabular}

*Hasil rata-rata 3 kali ulangan

Hasil analisa produk nori di atas bila dibandingkan dengan hasil analisa bahan baku terdapat perbedaan nilai nutrisi yang cukup besar, khususnya kadar protein dan abu. Kadar protein bahan baku (rumput laut Porphyra, sp) adalah 28,60\%, dan kadar abu $17,80 \%$ setelah melalui proses pengolahan menjadi nori, kadar proteinnya meningkat menjadi 41,49\% sebaliknya kadar abu turun menjadi 4,99\%. Hal ini mungkin dipengaruhi oleh beberapa tahapan proses pengolahan diantaranya pada proses pencucian. Di mana proses pencucian rumput laut yang baru dipanen, dilakukan dengan menggunakan air laut. Setelah pencucian rumput laut tersebut langsung dijemur. Rumput laut kering inilah yang digunakan sebagai sampel dalam menguji nilai gizinya. Hal ini yang mempengaruhi tingginya kadar abu dari bahan baku akibat adanya garam-garam yang masih menempel pada rumput laut. Sebaliknya pada proses pembuatan nori, digunakan rumput laut kering. Sebelum dilakukan proses pembuatan nori rumput laut tersebut di cuci berulang-ulang dengan menggunakan air bersih, untuk mengeluarkan 
kotoran dan garam-garam yang menempel identifikasi asam amino dari produk nori pada rumput laut. Hal inilah yang yang dihasilkan, diperoleh 10 jenis asam mempengaruhi kadar abu pada produk nori amino yang terkandung didalamnya yaitu lebih rendah dibandingkan bahan bakunya. treonin, arginin, tirosin, meteonin,lisin, valin, Selanjutnya dilakukan proses pemotongan. asam glutamate, glisin, fenilalanin dan Pada proses pemotongan ini ukuran rumput laut menjadi lebih kecil. Dengan demikian dapat membantu mengeluarkan zat-zat penting dalam sel-sel rumput laut selama proses perebusan. Penambahan sedikit cuka pada proses perebusan, juga membantu mengkoagulasi protein. Selanjutnya proses pengeringan dilakukan untuk menghilangkan air dari produk sehingga diperoleh nori dengan kadar protein yang lebih tinggi Porphyra marcossi, nori impor dan nori dari dibandingkan bahan bakunya. Hasil Gracilaria sp, dapat dilihat pada Gambar 2.

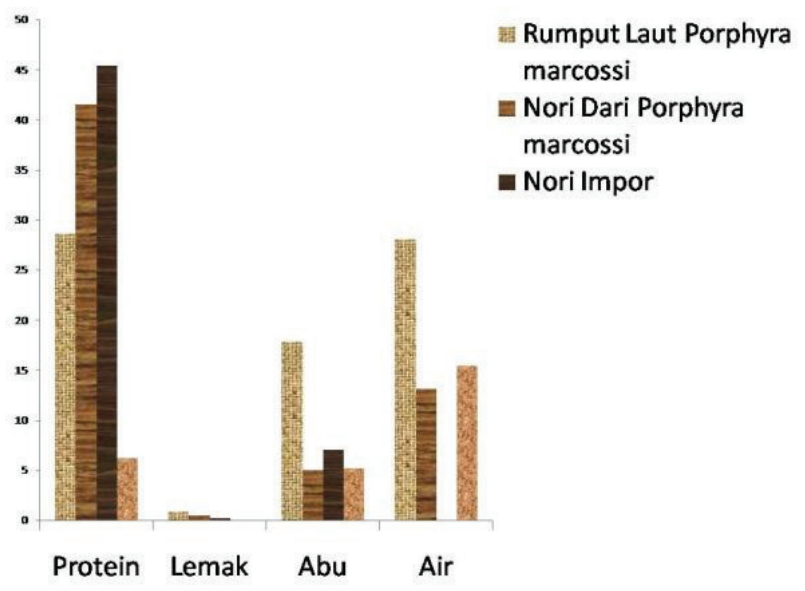

Gambar 2. Perbandingan Nilai Gizi Dari Porphyra marcossi, Nori Dari Porphyra marcossi, Nori Impor Dan Nori Dari Gracilaria sp.

Dari gambar tersebut di atas terlihat nilai gizi yang hampir sama dengan nori bahwa nori dari Porphyra marcossi memiliki impor. Sebaliknya nori dari Gracilaria $s p$ 
memiliki nilai gizi yang sangat kecil dibandingkan dengan nori impor.

Nori merupakan salah satu makanan yang memiliki kandungan nutrisi tinggi. Jenis-jenis asam amino yang terdapat dalam produk nori yang dihasilkan dalam penelitian ini berpengaruh pada kualitas gizinya. Dimana asam amino fenilalanin, valin, asam glutamate, glisin dan tirosin berperan dalam meningkatkan fungsi otak . Asam amino lisin, treonin, alanin dan tirosin, berperan dalam pembentukan protein otot maupun pembentukan kolagen untuk kulit. Selanjutnya asam amino metionin dan arginin berfungsi untuk menurunkan kolesterol darah dan meningkatkan fungsi hati. Asam amino tirosin berfungsi sebagai pemicu hormone dopamine, epinephrine, norepinephrin, melanin (pigmen kulit) serta hormone tyroid (Handayani, 2013; Ramdani, 2010).

Dalam Chapman (1970), memperlihatkan nilai nutrisi dari nori yang mengandung protein tinggi yaitu $25-30 \%$ dari berat kering, vitamin dan garam-garam mineral, khususnya yodium. Kandungan vitamin $\mathrm{C}$ nya 1,5 kali dari jeruk dan juga kaya akan vitamin B. Rasa spesifik pada nori berasal dari asam glutamate, glisin dan alanin. Kandungan karbohidrat dari nori merupakan campuran dari sulfat galaktan,terdiri dari $3-6$ anhydro-1galactosa, dengan unit d- dan 1-galaktosa dan $\beta, 1$ - 4 mannan. Ekstrak karbohidratnya merupakan karakter intermediate antara agarose dan k- karaginan. Sedangkan dalam Hiroyuki (1993), vitamin B12 dalam nori

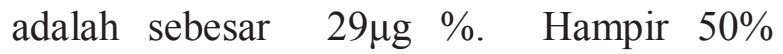
kandungan nori adalah EPA (Nisizawa, 2002).

Selanjutnya dalam Kusumanto (2014), menyebutkan bahwa nori dikenal sebagai sumber yodium dan mengandung vitamin $\mathrm{A}$, B1, B12, C dan vitamin E. Sedangkan kandungan mineral meliputi kalsium, seng, besi, selenium dan tembaga.

Selain dapat dikonsumsi langsung sebagai makanan ringan, nori juga digunakan sebagai hiasan dan penyedap berbagai masakan Jepang, misalnya pemberi rasa pada pengolahan mie dan sup, serta lauk sewaktu makan nasi dan biasanya ditambahkan ke dalam makanan ringan dan renyah seperti senbei. Senbei adalah makanan ringanyang renyah atau disebut juga crackers berbentuk bulat dan pipih. (Yamamoto, 1990 dalam Teddy,2009).

Dalam Wikipedia (2012), ukuran standar satu lembar nori di Jepang adalah $21 \mathrm{~cm} \times 19 \mathrm{~cm}$ yang kemudian dipotongpotong tergantung pada keperluannya. 
Dilihat dari ukuran besarnya, nori terdiri dari beberapa jenis:

- Yakinori ukuran standar: nori tawar untuk menggulung temakizushi dan makizushi.

- Yakinori tipe setengah: satu lembar nori ukuran standar dibagi dua, digunakan untuk membungkus seluruh bagian onigiri.

- Yakinori tipe sepertiga: satu lembar nori dibagi tiga, diletakan di bagian dasar onigiri sehingga mudah dipegang dengan tangan.

- Ajitsuke nori atau okazunori: satu lembar nori standar yang sudah diberi bumbu garam dapur, kecap asin, gula atau mirin dipotong menjadi 8 atau 12 potongan kecil. Pada umumnya dimakan sebagai teman makan nasi sewaktu sarapan pagi atau dimakan begitu saja sebagai makanan ringan.

- Mominori: ajitsuke nori yang sudah diberi bumbu garam, kecap asin, gula atau mirin dan dicabik-cabik sampai menjadi potongan berukuran kecil yang tidak seragam. Digunakan sebagai hiasan pada makanan Jepang seperti donburi atau chirashizushi.

- Kizaminori: yakinori yang dipotong halus-halus dengan ukuran seragam, berfungsi sebagai hiasan seperti mominori .

Aonori: nori berwarna hijau berbentuk serbuk kasar berukuran 2 - 3 mm yang ditaburkan di atas okonomiyaki, takoyaki dan yakisoba. Berbeda dengan bahan baku untuk nori standar, aonori menggunakan alga berwarna hijau jenis Monostroma dan Enteromorpha.

Nori banyak dibutuhkan di restoranrestoran Cina dan Jepang, yang menyiapkan menu siap sajinya. Produk nori yang dikonsumsi saat ini masih diimpor dari Negara Jepang, Korea, China dan Amerika Serikat.

\section{Prospek Pengembangan Rumput Laut}

\section{Porphyra sp di Indonesia}

Dari uraian di atas terlihat bahwa rumput laut Porphyra $\mathrm{sp}$ ini memiliki keunggulan-keunggulan dibandingkan tumbuhan lainnya. Kadar proteinnya cukup tinggi bahkan memiliki asam amino argininyang biasanya terdapat pada protein hewani, sebaliknya kadar lemaknya sangat rendah. Dengan demikian jenis rumput laut ini perlu dipertimbangkan untuk dikembangkan penggunaannya lebih luas lagi terutama untuk kaum vegerarian dan untuk perbaikan gizi masyarakat. Khusus untuk rumput laut jenis Porphyra marcossi dapat 
digunakan untuk memproduksi nori di dalam negeri, mengingat nilai gizinya yang dapat bersaing dengan nori impor.

Bila ditinjau dari teknologi pengolahan rumput laut Porphyra sp menjadi nori terlihat bahwa teknologi pengolahannya cukup sederhana dan mudah sehingga dapat dikembangkan pada industry rumah tangga yang bila ditekuni dengan baik dapat meningkatkan penghasilan keluaraga. Teknologi pengolahan ini dapat terus dikembangkan sejalan dengan perkembangan diversifikasi produk olahan jenis rumput laut ini.

Produk nori yang beredar di Indonesia sampai saat ini masih di impor dari Jepang, Korea, China dan Amerika Serikat. Nori banyak dibutuhkan di restoran-restoran China dan Jepang yang menyiapkan menu siap sajinya. Hal ini memperlihatkan kebutuhan nori di dalam negeri cukup besar. Dilain pihak bahan baku yang dibutuhkan untuk pembuatan produk ini tersedia walaupun pemanenan masih dilakukan secara alamiah. Itu berarti rumput laut ini termasuk rumput laut komersial sehingga perlu dipikirkan pembudidayaannya. Budidayanya tidak terlalu sulit, dimana panen dapat dilakukan di saat tanaman berumur sekitar 45 hari dan setelah panen pertama, rumput laut masih bisa dipanen berulangkali dengan masa istirahat sekitar 10 hari (FAO, 2013).

Dengan demikian pengembangan usaha rumput laut dalam bidang budidaya maupun industri pengolahannya mampu memberdayakan masyarakat secara luas. Selanjutnya akan berdampak pada pergerakan ekonomi lokal, regional dan nasional. Di mana issu penting saat ini adalah industrialisasi rumput laut yang telah ditindaklanjuti melalui nota kesepahaman mengenai pengembangan kawasan budidaya dan industri rumput laut di tujuh propinsi yakni: propinsi NTT, NTB, Sulawesi Tengah, Maluku, Maluku Utara, Sulawesi Tenggara dan Sulawesi selatan (Cocon, 2012). Selanjutnya dikatakan Nota kesepahaman yang dibangun melibatkan 6 lembaga/ kementerian yakni Kementerian Kelautan dan Perikanan, Kementerian PDT, Kementerian Perindustrian, Kementerian Perdagangan, Kementerian Koperasi dan UKM, serta Badan Koordinasi Penanaman Modal. Diharapkan dengan nota kesepahaman ini, jenis rumput laut Porphyra sp khususnya Porphyra marcossi ini juga dapat dikembangkan usaha budidaya maupun industri pengolahannya di Maluku, yang merupakan salah satu daerah pengembangan kawasan budidaya dan industri rumput laut di Indonesia. 


\section{Kesimpulan dan Saran}

\section{Kesimpulan}

Berdasarkan hasil penelitian di atas, dapat ditarik beberapa kesimpulan:

1. Rumput laut Porphyra marcossi mempunyai nilai gizi yang cukup tinggi yaitu: protein $28,60 \%$; lemak $0,83 \%$; abu $17,80 \%$ dan air $28,09 \%$.

2. Produk Nori mempunyai nilai gizi: protein 41,49\%; lemak 0,44\%; abu 4,99\%; air 13,14\% serta 10 jenis asam amino yaitu treonin, arginin, tirosin, meteonin, lisin, valin, asam glutamat, glisin, fenilalanin dan alanin.

3. Teknologi pengolahan Nori cukup sederhana dan mudah dikembangkan dalam industri rumah tangga untuk meningkatkan pendapatan keluarga.

4. Kebutuhan Nori dalam negeri dapat dipenuhi dengan adanya indutri pengolahan nori berbasis sumber daya alam lokal.

\section{Saran}

Perlu dilakukan penelitian lanjutan untuk melihat keunggulan produk nori lokal dibandingkan nori impor serta prospek pengembangannya di dalam negeri.

\section{Daftar Pustaka}

Anonymous, 2010, Rumput Laut Sebagai Pangan Fungsional. Warta Pasarikan Edisi September 2010, Volume 85, Direktorat Jenderal Pengolahan dan Pemasaran Hasil Perikanan, Kementerian Kelautan dan Perikanan, Diakses 7 Agustus 2013.

Aslan, M.L., 1998, Rumput Laut, Seri Budidaya, Penerbit Kanisius.

Chapman, V.J., 1970, Agar-agar in Seaweeds and Their Uses. London: Methew and Co. Ltd.151-195p.

Chapman, V.J., Chapman, D.J., 1980, Seaweed and their uses. In Production andUntilization of Product from Commercial Seaweed, Roma: FAO Fisheries Technical Paper.

Cocon, 2012, Status Rumput Laut Indonesia Peluang dan Tantangan, Direktorat Produksi, Ditjen Perikanan Budidaya.

Departemen Kelautan Dan Perikanan (DKP), 2009, Perekayasaan Teknologi Pengolahan Nori. Balai Besar Pengembangan Dan Pengendalian, Hasil Perikanan, Fish 
Blogs, http://informasibudidayaku.bl ogspot.com/2009 07 01_archive.ht $\underline{\mathrm{ml}}$, Diakses 4 Desember2012.

Desrosier, N.W., 1988, Teknologi Pengawet Pangan, Penerbit Universitas Indonesia (UI- Press).

Food, and Agriculture Orgaization (FAO), 2013, Porphyra spp, Culture Aquatic Species Information Programme, e-Buletin FAO, Powered by FIGIS, Diakses 20 Mei 2013.

Gaman, P.H., dan K.D., Sherrington, 1994, Ilmu Pangan, Pengantar Ilmu Pangan Nutrisidan Mikrobiologi. Edisi Kedua Gajah Mada University.

Handayani, E., 2013, Klasifikasi Asam Amino dan Fungsinya, http://organiksmakma3b08.blogspot. com/2013/04/klasifikasi-asamamino-dan-fungsinya_5.html? $\mathrm{m}=1$. Diakses 9 Februari 2015.

Hatta, A.M., E., Hermiati dan Luthfie Hutuely, 1993, Pengamatan Beberapa Jenis Makroalge Di Daerah Maluku Dan Pemanfaatannya Sebagai Sayur Laut, Lembaga Ilmu Pengetahuan Indonesia, Ambon.
Hiroyuki

N,

1993,

http://www.rawfood.com/products/0 372.html. Diakses tanggal 10 Desember 2008.

Korringga P 1976, Farming Marine Organisms Low In The Food Chain. Amsterdam,Oxford, New York: Elsevier Scientific Publishing Company.

Kuda T, Makiko T, Hishi T, Araki Y, 2004, Antioxidant Properties Of Dried "Kayamo- Nori" a brown alga Scytosiphon lomentaria (Scytosiphonales) Vinogradova.J. Food Chem. 89:617-622

Kusumanto D, 2013, Nori Produksi Indonesia Akan Disukai Dunia. http://m.kompasiana.com/post/read/ 626377/1/apakah-indonesia-mampumemproduksi-nori-dari-rumputlaut.html. Di akses 2 Februari 2015.

Kusumanto D, 2014, Nori . Nori makanan super khas Jepang untuk diet berbahan rumput laut Porphyra.http://tekyang.blogspot.co $\underline{\mathrm{m} / 2014 / 10 / \text { nori.html }}$. Diakses 3 Februari 2015.

Lisa C, 1999, Porphyra Human Consumption. Marine Botany. 
Monterey Bay Aquarium Reseach Institute.

Marine Biological Institute. 106 p. Othmer, 1968, "Seaweed Colloids". Encyclopedia Of Chemical Technology, No.17:763 - 784 .

Nisizawa K. 2002, Seaweeds Kaiso. Japan Seaweed Association. Tokyo.

Ramdani, D., 2010, Asam Amino Esensial dan Non Esensial. Artikel, Di akses 9 Februari 2015.

Soegiarto, A., Sulistijo, Atmadja, W.S., 1978, Rumput Laut (Algae): Manfaat, Potensi dan Usaha Budidaya, Jakarta: LON-LIPI.

Standar Nasional Indonesia, 1992, Cara Uji Makanan Dan Minuman, SNI 01 2891 - 1992, Badan Nasional Indonesia.

Tanikawa, E., 1971, Marine Product In Japan, Tokyo, Koseisha Koseikaku Co. Ltd.

Teddy, M.S., 2009, Pembuatan nori Secara Tradisional Dari Rumput Laut Jenis Gracilaria sp., Skripsi Program Studi Teknologi Hasil Perairan. Fak. Perik. Dan Ilmu Kelautan. IPB.

Terramoto, T., 1990, Seaweed, their chemistry and uses. In Science of
Processing Marine Food Product, Vol I. Motohiro T, Kaduto H, Hashimoto,K., Hashimoto, K., Kayoni, M., Tokuraga,T., editor. Japan International Centre.142$156 \mathrm{p}$.

Trono, Jr.G.C., and E.T., Ganzon - Fortes, 1988, Philippine Seaweeds, Marine Science Institute University Of The Philippine Diliman, Quenzon City.

Wikipediea, 2012, Nori. 1 Februari 2012, http://id.m.wikipedia.org/wiki/Nori, 4, Desember 2012.

Winarno, F.G., 1990, Teknologi Pengolahan Rumput Laut. Jakarta: PT. Gramedia Pustaka Utama, Jakarta. 